\title{
ANALYSIS OF ELEMENTARY SCHOOL STUDENT SKILLS IN WRITING DESCRIPTIVE TEXTS
}

\author{
Daden Sopandi ${ }^{1}$ \\ ${ }^{1}$ MI Malingping \\ ${ }^{1}$ dsopandi1@gmail.com
}

\begin{abstract}
The purpose of this study was to determine the ability of students to write descriptive texts. This study was designed as a descriptive quantitative study and was carried out in MI Malingping located in Sukabumi Regency. The number of samples in this study was 40 students. In this study, researchers used a writing test as a research instrument where students were asked to write descriptive texts based on the topics given to them. In this study, researchers analyzed 5 descriptive text components written by students such as content, organization, grammar, vocabulary, and mechanics. From the results of the study, the researchers found that the average score of students in descriptive text writing was 51.87 and that meant their writing skills in a descriptive text could be categorized at a low level.
\end{abstract}

Keywords: Writing Skill, Descriptive

\begin{abstract}
Abstrak
Tujuan dari penelitian ini adalah untuk mengetahui kemampuan siswa dalam menulis teks deskriptif. Penelitian ini dirancang sebagai penelitian kuantitatif deskriptif dan dilakukan di MI Malingping yang berlokasi di Kabupaten Sukabumi. Jumlah sampel dalam penelitian ini adalah 40 siswa. Dalam penelitian ini, peneliti menggunakan tes menulis sebagai instrumen penelitian dimana siswa diminta untuk menulis teks deskriptif berdasarkan topik yang diberikan kepada mereka. Dalam penelitian ini, peneliti menganalisis 5 komponen teks deskriptif yang ditulis oleh siswa seperti konten, organisasi, tata bahasa, kosa kata dan mekanika. Dari hasil penelitian tersebut, peneliti menemukan bahwa skor ratarata siswa dalam penulisan deskriptif teks adalah 52.428 dan itu berarti keterampilan menulis mereka dalam teks deskriptif dapat dikategorikan dalam tingkat rendah.
\end{abstract}

Kata Kunci: Kemampuan Menulis, Deskriptif

\section{INTRODUCTION}

As an international language, English is one of the most important languages in the world. many science reference sources use English in its delivery. besides English is not only used in the United Kingdom but has been made a mandatory language by several countries and used as a means of communication. Communication is done not only in speech but also in the middle of writing because good writing can give a good message and also understood by readers (Tarigan, 1986). The mastery of good English is deemed as having an edge and can bring a lot of advantages in many ways. This international language is not only used for communicational purposes but also in the fields of technology, commerce, education and many other aspects of life (Abdullah, 2013).

In learning English, there are four language skills, which are developed in learning in schools such as: listening, speaking, reading, and writing. Listening and reading are receptive skills while speaking and writing are productive skills. Most students consider listening and 
reading more difficult than speaking and writing. In fact, they also find difficulties in learning productive skills, especially in writing skills (Tarmizi, Mertosono, \& Hastini, 2018).

The basic process of learning in elementary schools in improving writing skills is usually done by training students to be able to write clearly and be read first. Good writing and can be read clearly can make the writing easier to read. After the ability to write neatly increases, students can develop towards developing ideas and expressing their own thoughts in written form. it can improve students' ability to write

One aspect of language that must be mastered by students is the aspect of writing skills. One of the papers that students must learn is writing experience. Writing experience is one form of narrative writing that is no different from writing other essays. In writing experience, it is necessary to arrange the story from that experience.

In MI Malingping, one of the texts taught for the students is Descriptive text. According to Hyland (2002), writing is learned, rather than taught, and the teacher's best method is flexibility and support. According to the English teacher, students' writing skills in the descriptive text need much improvement to get better writing results than now. It is intended that students can explain and illustrate their ideas about certain things.

Slamet (2007) states that training students in writing must be gradual and continuous. The ability to write when an adult is different from when he was in elementary school. when schooling, their knowledge, and experience is very limited. with increased experience and knowledge, someone as an adult has better writing skills. the ideas and ideas put forward became more diverse. therefore students need to be sharpened and trained in their writing skills early on.

In writing a descriptive text, the students in MI Malingping sometimes found some difficulties although they have been guided by their teachers to write it. There were some difficulties that students face during writing the descriptive paragraph.

The first problem is writing letters. In writing letters, students often incorrectly write letters. Some mistakes in writing letters are procedures for writing capital letters and lowercase letters. They mistakenly write letters at the beginning of sentences, names of people, names of important places, names of positions, titles of essays, and so on. This is often found in learning to write in schools. Writing mistakes in learning Indonesian clearly disturbs the success of students. These mistakes must be handled in order to achieve learning objectives.

Second is punctuation errors. This error is often the author encountered at all levels of education both in schools and colleges. the most common problem arises is the misuse of 
periods and commas. Some of the reasons for errors in writing letters and punctuation from the students' side of the line are the lack of understanding the procedures for writing and punctuation then do not consider the importance of proper writing and punctuation procedures and do not want to familiarize the procedures for writing letters and punctuation correctly.

Another fundamental problem is that if a teacher outside the Indonesian language studies does not consider important about how to write in accordance with applicable language rules. This phenomenon is a common thing. When we observe in general and carefully, it seems that only teachers in the field of language studies are very concerned about writing techniques that are in accordance with the spelling rules. If only teachers of Natural Sciences, Social Sciences, Mathematics, and so on, write according to the rules of good and correct spelling, of course, the students will be followed. So what is provided by learning by Indonesian language teachers, it should also be done by other teachers of other fields of study. Based on problem above, the researcher wants to find out the students' writing skill in descriptive text because writing needs more attention because students get some difficulties in mastering it especially in writing descriptive text (Sesar, Yusuf, Baso, \& Makassar, 2018)

\section{METHOD}

The design of this research was descriptive qualitative research. Gay, Mills, \& Airasian, (2012) said that descriptive research determines and describes the things are. In this problem, descriptive research was used to analyze the students' writing skills in the descriptive text made by the fifth-grade students of MI Malingping.

This research deals with the purpose of knowing the students' skill in writing descriptive text. In analyzing the students' written work, the researcher was helped by the raters who will determine the students' writing scores in descriptive text. To determine the students' writing score, the researcher used the guidance from the following scoring rubric for descriptive text writing.

The population in this study were Malingping students. The sampling technique uses the Purposive Sampling method. Based on data on the number of students, the researchers took samples of class $\mathrm{V}$, amounting to 40 students. This is done to make it easier for researchers to collect data on student learning outcomes in addition to the number of students in one class is sufficient rules of research sampling. To obtain research data, the research method used is the observation method which is used as a data collection technique. Researchers also use the task of making one of the tools that can be used to obtain data in accordance with the objectives. 


\section{RESULTS AND DISCUSSION}

\section{Results}

The activity carried out in this research was to carry out a learning plan that had been prepared previously, namely in the form of activities to compile descriptive texts. The results of this study, researchers analyzed the components in descriptive text. The results of the analysis consist of aspects of content, organization, grammar, vocabulary, and mechanics which can be seen in the table below.

Table 1. Descriptive Text Analysis Results

\begin{tabular}{clcc}
\hline No & \multicolumn{1}{c}{ Aspect } & Score & Level \\
\hline 1 & Content & 54.68 & Poor \\
2 & Organization & 51.25 & Poor \\
3 & Grammar & 55.21 & Poor \\
4 & Vocabulary & 40.65 & Poor \\
5 & Mechanics & 60.35 & Poor \\
\hline & Average & $\mathbf{5 2 . 4 2 8}$ &
\end{tabular}

Based on the data above, it can be taken an average score of 52.428 where it is categorized as a poor level. These results indicate if elementary school children are very difficult in terms of writing where they fall behind in all aspects of writing.

\section{Discussion}

Based on the results of the study, several problems emerged based on the five aspects studied. These results show a picture of the writing skills of elementary school students where the average of each aspect. First, about content, students have difficulty developing their ideas in written form. Instead of describing what is on the mind, the writing made actually causes confusion for the readers. The number of ambiguous sentences makes the writing made rather difficult for the reader to digest. The average student has not been able to pour the main ideas into flowing writing.

Besides the essence of the paragraph written is usually not seen clearly. At the end or beginning of a sentence which is usually in the form of a core sentence, the students' writing usually does not contain the core sentence. Students randomly place the core in the paragraph.

Another problem is the grammar. Grammar is also an important element in writing because we learn such as tense, types of sentences, parts of speech in grammar. Several parts of speech are included in writing accuracy, for example, nouns, adverbs, adjectives, conjunctions, and prepositions (Zainab, Usman, \& Bochari, 2016). The difficulty in using the grammar is based on the students' ignorance in arranging word for word into a correct sentence. 
Even students' lack of vocabulary also becomes a reason in the difficulty of students composing sentences with the correct grammar. This can be a problem because students will have difficulty in developing their ideas into writing.

Students also sometimes have difficulty when finding words that have two words in English. students will be confused about which word to use even though the meaning is the same. That is due to the lack of vocabulary students and are not accustomed to using the word.

For primary school students, student vocabulary is indeed still low. Their lack of experience in daily life, where they still live on a family scale alone makes students only have a vocabulary improvised. The experience of students outside of family life is very minimal, this is based on the age of those who are still fairly children.

\section{CONCLUSION}

Based on the results of the study, the results of the analysis carried out showed that the skills of elementary school students in writing descriptive texts were classified as low. The results obtained from observations indicate that the biggest factor affecting it is the ability of students in the grammar aspect and the lack of student vocabulary.

In the process of improving vocabulary, students are directed to read more in advance so that their vocabulary is increased and they can learn grammar from existing text.

\section{REFERENCES}

Abdullah, A. T. H. bin. (2013). Error Analysis on The Use of The SimpleTense and The Simple Past Tense in Writing Essays Among TESL College Students. International Journal of Education and Research, 1(12), 1-12.

Gay, L. ., Mills, G. E., \& Airasian, P. (2012). EDUCATIONAL RESEARCH: Competencies for Analysis and Applications.

Hyland, K. (2002). Authority and invisibility: Authorial identity in academic writing. Journal of Pragmatics, 34(8), 1091-1112. https://doi.org/10.1016/S0378-2166(02)00035-8

Slamet (2007). Dasar-dasar pembelajaran bahasa dan sastra indonesia di sekolah dasar. Surakarta: Lembaga Pengembangan Pendidikan (LPP) UNS dan UPT. Penerbitan dan Percetakan UNS Press

Sesar, R., Yusuf, T., Baso, F. A., \& Makassar, U. M. (2018). The application of contextual teaching and learning approach (ctl) to enhance the students' writing ability in descriptive text. Jurnal Keguruan Dan Ilmu Pendidikan (JKIP), 5(1), 18-24.

Tarmizi, Mertosono, S. R., \& Hastini. (2018). DEVELOPING SKILL IN WRITING RECOUN TTEXT THROUGH FREE WRITING. ELTS (English Language Teaching Society), 6(1), 1-12. 
Tarigan, H. G. (1986). Menulis sebagai suatu keterampilan berbahasa. Bandung: Angkasa.

Zainab, Z., Usman, S., \& Bochari, S. (2016). AN ERROR ANALYSIS OF CONJUNCTIVE ADVERBS USED BY THE TENTH GRADE STUDENTS. E-Journal of English Language Teaching Society (ELTS), 4(2), 1-11. 